\title{
Electrophysiological Effect of Acupuncture in the Carpal Tunnel Syndrome Case
}

\author{
Hayriye Alp \\ Necmettin Erbakan University, GETAT CENTER, Konya, Turkey. \\ Corresponding Author: Hayriye Alp, Necmettin Erbakan University, GETAT CENTER, Konya, Turkey. \\ Received date: April 22, 2021; Accepted date: April 27, 2021; Published date: May 08,2021 \\ Citation: Hayriye Alp (2021) Electrophysiological Effect of Acupuncture in the Carpal Tunnel Syndrome Case J, Clin Med Rev and Rep. 3(5); \\ DOI:10.31579/2690-8794/083
}

Copyright: (C) 2021, Hayriye Alp, This is an open access article distributed under the Creative Commons Attribution License, which permits unrestricted use, distribution, and reproduction in any medium, provided the original work is properly cited.

\begin{abstract}
Carpal tunnel syndrome (CTS) is the most common entrapment neuropathy and occurs as a result of compression of the median nerve in the carpal tunnel at the wrist. The classic symptom in patients with CTS is paresthesia (numbness, burning, tingling) and pain in the median nerve distribution area of the hand, especially at night. A 24-year-old female patient presented to GETAT polk with the diagnosis of mild carpal tunnel syndrome after examination and EMG after the complaint of numb tingling in the hand in the neurology outpatient clinic. The patient was using Parkyn (pramipexole dihydrochloride monohydrate) $25 \mathrm{mg}$. Acupuncture was applied to the patient for 10 sessions. Disposable sterile acupuncture needles were applied to the PC-6, H-7, LU-9, H-7, SI-3 points $(0.22 \times 13 \mathrm{~mm}, 0.22 \times 1.5 \mathrm{~mm}$ Hua Long). The sessions lasted 20 minutes. The sessions were done first twice a week, then once a week. The patient was prescribed Vitamin B1 + B6 supplements. After 10 sessions of acupuncture, the EMG was repeated. The EMG result of the patient was normal. Parkyn was cut by neurology, Lyrica (pregabalin) was switched to $150 \mathrm{mg}$. The patient's need for medication was also reduced.
\end{abstract}

Key words; carpal tunnel syndrome, acupuncture, emg

\section{Introduction}

Carpal tunnel syndrome (CTS) is the most common entrapment neuropathy and occurs as a result of compression of the median nerve within the carpal tunnel at the wrist. The classic symptoms in patients with CTS are paresthesia (numbness, burning, tingling) and pain occurring in the median nerve distribution area, especially at night $[1,2,3,5]$. In the etiology of CTS, there are many reasons such as muscle and tendon anomalies, gout tenosynovitis, rheumatoid arthritis, diabetes mellitus (DM), amyloidosis, acromegaly, myxedema, obesity, pregnancy, sarcoidosis, and occupational causes [1]. CTS is treated conservatively or surgically. Conservative methods include the use of splints, non-steroidal anti-inflammatory drugs, corticosteroid injection into the carpal tunnel, physical therapy modalities (ultrasound, Transcutaneous Electrical Nerve Stimulation (TENS), iontophoresis, laser), tendon and nerve shifting exercises, activity or occupational modification, vitamin B6 [6]. In addition, acupuncture and yoga have been shown to reduce symptoms in CTS [8]. Acupuncture is an ancient Chinese treatment method in the treatment of various diseases, where needles are placed in the areas where the meridians pass [9]. Acupuncture for various rheumatic diseases and painful conditions (arthritis, neck and shoulder pain, sciatica), neurological diseases (peripheral neuropathies, headaches, trigeminel neuralgia, facial paralysis, vertigo, menier disease, cerebrovascular diseases, paraplegia, poliomyelitis, epilepsy psychiatric diseases diseases, schizophrenia, drug addictions) and many other diseases [10,11].

\section{Case}

A 24-year-old female patient presented to GETAT polk with the diagnosis of mild carpal tunnel syndrome after examination and EMG after the complaint of numb tingling in the hand in the neurology outpatient clinic. The patient was using Parkyn (pramipexole dihydrochloride monohydrate) $25 \mathrm{mg}$. 10 sessions of acupuncture were applied to the patient. Disposable sterile acupuncture needles were applied to the PC-6, H-7, LU-9, H-7, SI-3 points $(0.22 \times 13 \mathrm{~mm}, 0.22 \times 1.5 \mathrm{~mm}$ Hua Long). The sessions lasted 20 minutes. The sessions were done first twice a week, then once a week. The patient was prescribed Vitamin B1 + B6 supplements. 


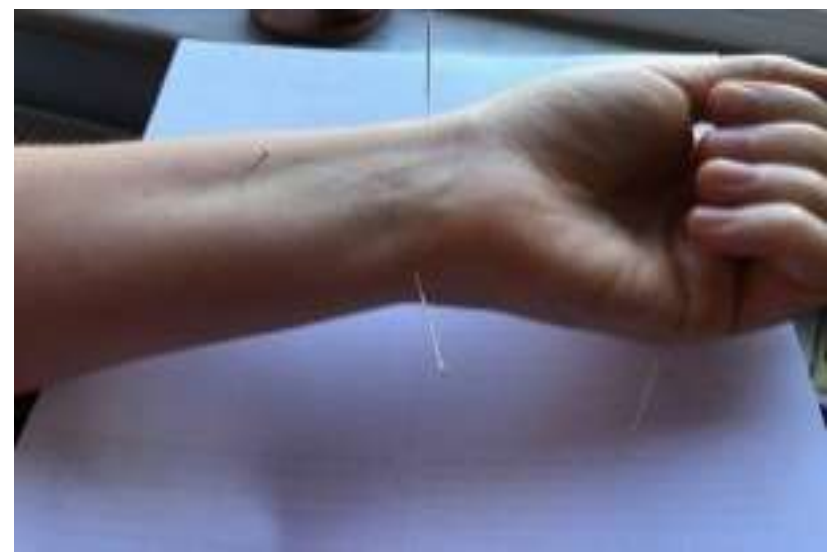

Ficture.1 acupuncture points

\section{Result}

After 10 sessions of acupuncture, the EMG was repeated. The EMG result of the patient was normal. Parkyn was cut by neurology, Lyrica (pregabalin) was switched to $150 \mathrm{mg}$. The patient's need for medication was also reduced.

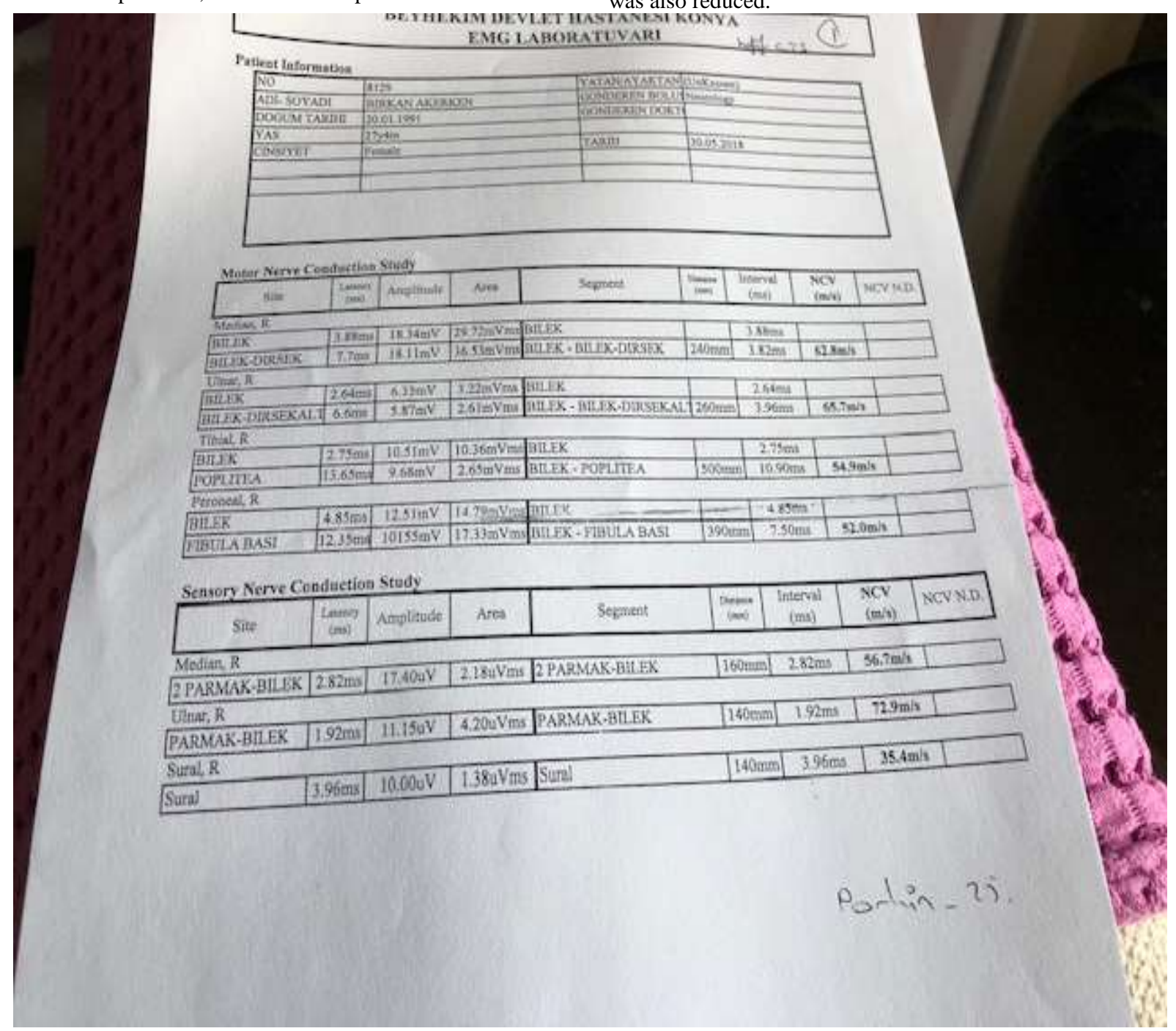




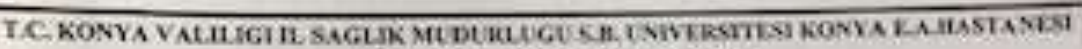

(2) $=N$ ENMG LABORATUVARI

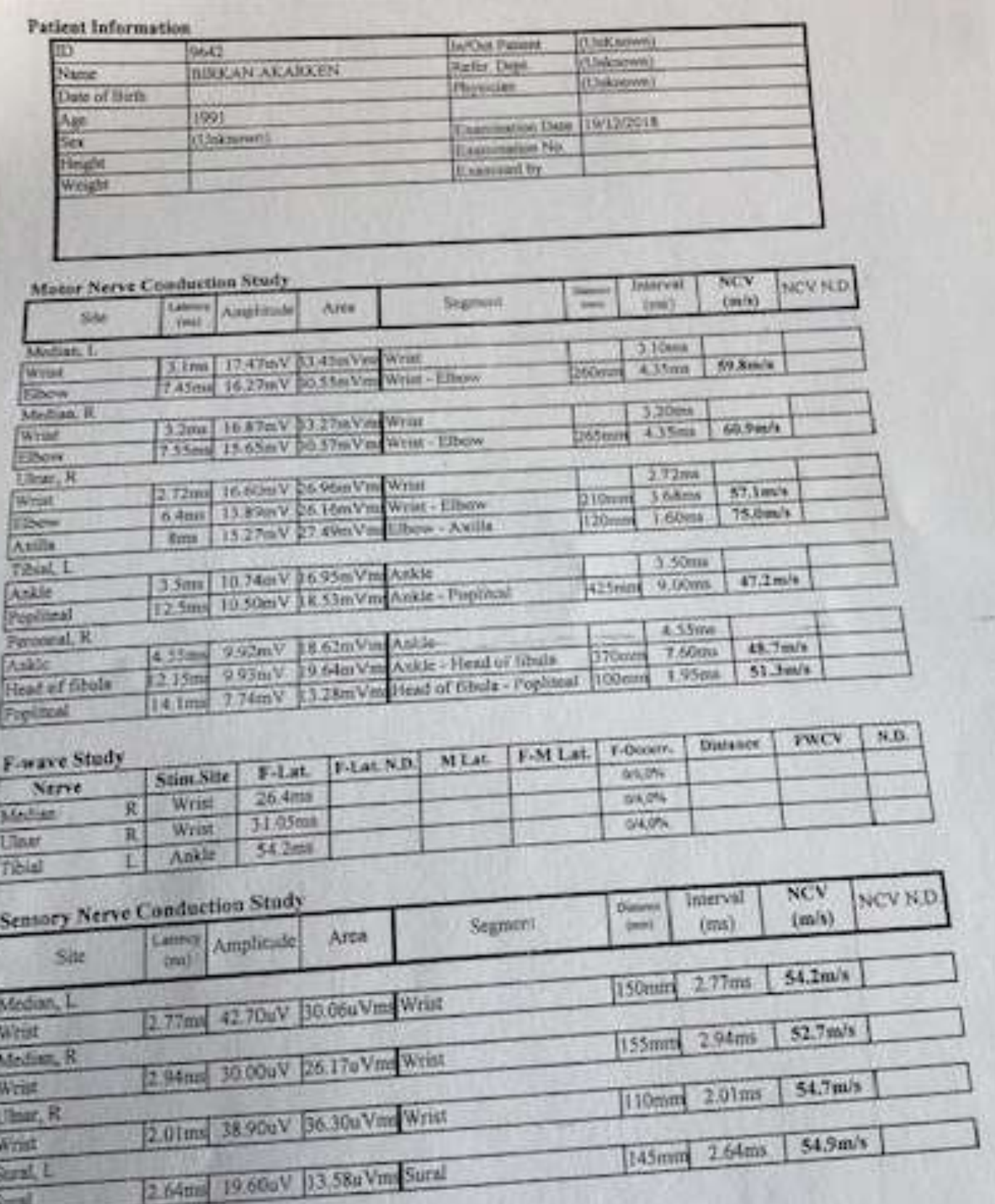

SEI

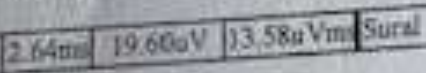




\section{Discussion}

If the continuity of the nerve sheath is preserved, following the degeneration, the nerve regenerates at a rate of approximately $1 \mathrm{~mm}$ per day towards the distal of the injury site.

The thought that is generally emphasized in the pathophysiology of CTS is that the median nerve is damaged in the carpal tunnel as a result of mechanical compression and ischemia. The combination of ischemic changes and prolonged mechanical pressure causes changes in the myelin sheath [3]. In studies conducted in the tenosynoviums of patients with carpal tunnel syndrome, the presence of a non-inflammatory ischemiareperfusion trauma resulting in progressive edema and fibrosis has been shown in the etiology of CTS [15, 18].

CTS surgery is the most common hand surgery in the world [16]. In CTS syndrome, up to $65 \%$ of patients are bilaterally affected [17]. In bilateral cases, the dominant hand is usually held earlier and more severely, while in cases with unilateral involvement, the dominant hand is often held [2, $1,16]$. In carpal tunnel syndrome, pressure in the tunnel increases significantly [13]. In studies performed, carpal tunnel pressure was found to be $2.5 \mathrm{mmHg}$ in normal volunteers, while it was $32 \mathrm{mmHg}$ in patients with CTS [14].

Approximately $70-80 \%$ of acupuncture points are the same as trigger points [19] and it has also been determined that most of them are the same as the motor points of the muscles [20].

Receptors such as nociceptors, meissner bodies, krause bulbs, and Golgi tendon organs are abundant in acupuncture points [21]. Acupuncture can stimulate large sensory afferent fibers and suppress the perception of pain as understood in gate control theory. Second, it provides pain control effect by inducing the release of opiate-like endogenous material by the action of needle sticking as a painful stimulus [22].

Sakai et al. reported that the sympathetic-parasympathetic autonomic systems were affected by manipulation in acupuncture treatment [23].

It is included in CTS as one of the locomotor system diseases that are treated palliative with acupuncture [24]. Acupuncture, one of the best accepted complementary and alternative medical treatments, has been documented in the Chinese medical literature as an effective treatment for hand numbness and weakness. Additionally, acupuncture has been declared as a beneficial intervention for CTS for more than a decade by the National Institute of Health. Its superiority over placebo in CTS has been proven in numerous studies [25].

Yang et al. In a randomized controlled study performed by applying oral steroid and acupuncture in the treatment of 77 patients diagnosed with CTS in 2009, they showed that acupuncture was as effective as low-dose oral steroid therapy in mild-moderate CTS [12].

Kumnerde et al. administered 10 sessions of electro-acupuncture twice a week and volar neutral night splint at night for 5 weeks to a mild to moderate CTS patient aged 27-67 years. The results measured with mm VAS concluded that acupuncture therapy seems to be an appropriate choice for CTS patients with predominantly hand pain [25].

\section{Conclusion}

As a result, acupuncture and vitamin B supplements can be used effectively in the treatment of mild to moderate carpal tunnel syndrome.

\section{References}

1. Beyazova M, Gökçe-Kutsal Y. (2000)Fiziksel Tıp ve Rehabilitasyon. Şenel K. El ve El Bileği Ağrısı, Güneş Kitabevi; 1455-1464.
2. Thomas M.A, Felsenthal G, Fast A, Young M (2005): Peripheral Neuropathy. Joel A. DeLisa, Bruce M. Gans, Nicolas E. Walsh: Physical Medicine and Rehabilitation.dan, Dördüncü Bask1, Philadelphia,; 895-911.

3. Werner RA, Andary M. Carpal tunnel syndrome (2002): Pathophysiology and clinical neurophysiology. Clinical Neurophysiology; 113: 1373-1381.

4. Dammers JWHH, Veering MM, Vermeulen M. (1999)Injection with methylprednisolone proximal to the carpal tunnel: randomised double blind trial. BMJ 319: 884- 886.

5. Magee D.J. (2002)Orthopedic Physical Assessment, Dördüncü Bask1,; 355-423.

6. Nadler S. F, Schuler S, Nadler J.S.( 2005) Cumulative Trauma Disorders. Joel A. DeLisa, Bruce M. Gans, Nicolas E. Walsh: Physical Medicine and Rehabilitation.dan, DördüncüBask1, Philadelphia; 615-630.

7. Hayes E.P, Carney K, Wolf J, Smith J.M, Akelman E.( 2002) Carpal Tunnel Syndrome. Mackin E.J, Callahan A.D, Skirven T.M, Schneider L.H, Osterman A.L: Rehabilitation Of The Hand and Upper Extremity.den, Beşinci Baskı, St. Louis, CV Mosby; 643-659.

8. Garfinkel MS, Singhal A, Katz WA, et al.(1998) Yoga based intervention for carpal tunnel syndrome: randomized trial. JAMA; 280(18): 1601-1603.

9. Jaggar,DRP() History and basic introduction to veterinary acupuncture,Problems in Veterinary Medicine; 4:1-11.

10. Tekeoğlu İ. Temel Akupunktur. Zonguldak: Devlet Hastanesi Yayınları, 1988; 1- 23.

11. Sezen K. Akupuntur Teorik ve Pratik. 2002; 21-32.

12. Yang CP, Hsieh CL, et al(2009) acupuncture in patient with carpal tunnel syndrome a randomized controlled trial. Clin $\mathrm{J}$ Pain; 25: 327-333.

13. Sanz J, Lizaur A, Sanchez Del Campo F.(2005) Postoperative changes of carpal canal pressure in carpal tunnel syndrome: A prospective study with follow-up of 1 year. J Hand Surg [Br]; 30: 611-4.

14. Gelberman R, Hergenroeder P, Hargens AR, Lundborg G,Akeson W. (1981)The carpal tunnel syndrome: A study of canal pressures.J Bone Joint Surg [Am]; 63:380-3.

15. Freeland AE, Tucci MA, Barbieri RA, Angel MF, Nick TG. (2002) Biochemical evaluation of serum and flexor tenosynovium in carpaltunnel syndrome. Microsurgery; 22: 37885.

16. Giersiepen K, Spallek M. (2011) Carpal Tunnel Syndrome as an Occupational Disease review artıcle. Dtsch Arztebl Int. April; 108(14): 238-242.

17. MacKinnon SE, McCabe S, Murray JF, Szalai JP, Kelly L, Novak C, Kin B, Burke GB.( 1991) Internal neurolysis fails to improve the results of primary carpal tunnel decompression. Hand Surg [Am];16:211-8.

18. Bland JD, Rudolfer SM.(2003) Clinical surveillance of carpal tunnel syndrome in two areas of the United Kingdom, 19912001. J Neurol Neurosurg Psychiatry; 74:1674

19. Melzack R, Stillwell DM, Fox EJ. (1977)Trigger points and acupuncture points for pain correlation and implication. Pain; 3 : 3-23.

20. Liao SJ. Acupuncture points.(1975) Coincidence with motor points of skeletal muscles. Arch Phys Med Rehabil; 56: 550.

21. Kho H, Robertson EN. (1997)The mechanisms of acupuncture analgesia: review and update. Amer J Acupuncture; 25: 261-81.

22. Kim HA, Se o YI.(2003) Use of complementary and alternative medicine by arthritis patients in a university hospital clinic serving rheumatology patients in Kore a. Rheumatol Int; 23: 277 281. 
23. Sakai S, Hori E, Umeno K, Kitabayashi N, Ono T, Nishijo H.(2007) Specific acupuncture sensation correlates with EEGs and autonomic changes in human subjects. Auton Neurosci; 133: 158-69.
24. Abut M.(1992) Lokomotor sistem hastalıklarında akupunkturun etki mekanizmas1. Akupunktur Dergisi; 4: 19-29.

25. Kumnerddee W, Kaewtong A.(2010) Efficacy of acupuncture versus night splinting for carpal tunnel syndrome: a randomized clinical trial. J Med Assoc Thai. Dec; 93(12): 1463-9.
This work is licensed under Creative Commons Attribution 4.0 License

\section{To Submit Your Article Click Here: Submit Manuscript}

DOI: $10.31579 / 2690-8794 / 083$
Ready to submit your research? Choose Auctores and benefit from:

* fast, convenient online submission

* rigorous peer review by experienced research in your field

* rapid publication on acceptance

* authors retain copyrights

* unique DOI for all articles

* immediate, unrestricted online access

At Auctores, research is always in progress.

Learn more www.auctoresonline.org/journals/clinical-medical-reviewsand-reports 